\title{
Analysis of the type material of Planothidium delicatulum (Bacillariophyta) with the description of two new Planothidium species from the sub-Antarctic Region
}

\author{
Bart VAn de ViJver ${ }^{1,2^{*}}$, Carlos E. Wetzel ${ }^{3} \&$ Luc Ector $^{3}$
}

\author{
${ }^{I}$ Botanic Garden Meise, Research Department, Nieuwelaan 38, B-1860 Belgium; *Corresponding author e-mail: \\ bart.vandevijver@plantentuinmeise.be \\ ${ }^{2}$ University of Antwerp, Department of Biology, ECOBE, Universiteitsplein 1, B-2610 Wilrijk, Antwerpen, Belgium \\ ${ }^{3}$ Luxembourg Institute of Science and Technology (LIST), Environmental Research and Innovation Department \\ (ERIN), 41 rue du Brill, L-4422 Belvaux, Luxembourg
}

\begin{abstract}
During a survey of the freshwater diatom flora on the sub-Antarctic islands of the southern Indian Ocean, two new Planothidium species were observed, showing some resemblance to Planothidium delicatulum. Therefore, the type material of Achnanthidium delicatulum Kützing was analysed, a common species in northern hemisphere waterbodies that was later transferred to the genus Planothidium. Additionally the material of Types du Synopsis des Diatomées de Belgique n² 234, designated in 1980 as neotype for Achnanthes delicatula was investigated. This analysis showed that the population in Types $n^{\circ} 234$ is not conspecific with Achnanthidium delicatulum but in fact is a population of Planothidium galaicum. Both Planothidium species in the investigated Antarctic material are described as new to science: P. lilianeanum Van de Vijver sp. nov. and P. australodelicatulum Van de Vijver, C.E.Wetzel et Ector sp. nov. The new species can be differentiated based on differences in valve outline, presence of ridges and silica outgrowths on the rapheless valve, the structure of the raphe and the shape and size of the central area. Notes on the ecology and distribution of the new Antarctic species are added. Achnanthidium delicatulum is formally lectotypified.
\end{abstract}

Key words: Bacillariophyta, Planothidium, Antarctica, morphology, type material, lectotypification

\section{INTRODUCTION}

During a new survey of the monoraphid diatom flora of the sub-Antarctic islands, two unknown Planothidium species were observed, originally identified as Planothidium delicatulum (Kützing) Round et Bukhtiyarova (LE COHU \& MaILlard 1983; VAN De ViJver et al. 2002; Le CoHU 2005). The two unknown Planothidium taxa found on Iles Kerguelen and Iles Crozet in the southern Indian Ocean show a clear resemblance to $P$. delicatulum s.s. Unfortunately, comparison with the latter proved to be difficult as doubts have recently been raised on the typification of the name Achnanthidium delicatulum Kützing, basionym of Planothidium delicatulum (ÁLVAREZ-BLANCO \& Blanco 2013; RiauX-Gobin et al. 2018). For a long time the original material of Achnanthidium delicatulum Kützing, published in 1844, was thought to be lost and thus no more available (LANGE-BERTALOT \& RUPPEL 1980, p. 2). Consequently, Lange-Bertalot (in LANGe-Bertalot \& RuPPEL 1980) designated as "neotype" the slide $\mathrm{n}^{\circ}$ 234 of VAn Heurck "Types du Synopsis" preserved in the Natural History Museum, London, as n ${ }^{\circ}$ BM 26545 (VAN HeURCK 1880-1885). This neotypification was challenged by ÁLVAREZ-BLANCO \& BLANCO (2013) for two reasons: first, because the chosen neotype was in obvious conflict with the original description and illustrations, and secondly, because Kützing's published illustrations which are part of the original material (MCNEILL et al. 2012, art. 9.3) are available and could have been taken into account for lectotypification of the name (MCNeILL et al. 2012, art. 9.12, 9.13). However, Álvarez-Blanco \& BlANCO (2013) did not formally correct the mistake by designating a new lectotype.

Recently, several gatherings by Kützing from Wangerooge, the original locality of Achnanthidium delicatulum, were found in the Van Heurck Collection (BR, Belgium). Additionally, unmounted material from which slide $\mathrm{n}^{\circ} 234$ was prepared, was also found in the Van Heurck Collection (BR, Belgium).

The present paper describes two new Planothidium species from the sub-Antarctic islands: P. lilianeanum Van de Vijver sp. nov. and Planothidium autralodelicatulum Van de Vijver, C.E.Wetzel et Ector sp. nov. using LM and SEM observations, comparing both new taxa with already known taxa. The historic Achnanthidium delicatulum material from Kützing and Van Heurck is 
illustrated and discussed. Notes on the ecology of the new taxa are added.

\section{Material And Methods}

The past twenty years, aquatic, moss and soil samples were collected during several field campaigns on islands in the southern Indian Ocean (Prince Edward Islands, Iles Crozet, Iles Kerguelen and Heard Island). In the present study, samples from three archipelagos were further analysed: Prince Edwards Islands (46 $53^{\prime} 19^{\prime \prime} \mathrm{S}$, $\left.37^{\circ} 44^{\prime} 08^{\prime \prime E}\right)$, Iles Crozet $\left(46^{\circ} 24^{\prime} 41^{\prime \prime} \mathrm{S}, 51^{\circ} 45^{\prime} 22^{\prime \prime} \mathrm{E}\right)$ and Iles Kerguelen $\left(49^{\circ} 20^{\prime} 00^{\prime \prime} \mathrm{S}, 69^{\circ} 20^{\prime} 00^{\prime \prime} \mathrm{E}\right)$. The three archipelagos are located ca. 1000-2000 km from the coasts of South Africa and Australia, and have a typical oceanic cold climate. Mean annual temperature at the Port-aux-Français (Iles Kerguelen) weather station ranges $7.7^{\circ} \mathrm{C}$ in February (austral summer season) to $2.1^{\circ} \mathrm{C}$ in August (winter season). Annual precipitation exceeds often $3200 \mathrm{~mm}$, mainly in the form of rain and snow (FRENOT et al. 1997). The vegetation on the islands is mainly dominated by grasses and mosses. The native vascular flora consists of only 22 species occurring up to an altitude between 200 and $300 \mathrm{~m}$.

More information regarding sampling localities and methods is given in VAN DE ViJver et al. (2001, 2002, 2008). Table 1 lists all sub-Antarctic samples used in this study.

For comparison, the following historic material collected by Kützing and by Van Heurck was prepared for this study. Kützing sample ${ }^{\circ} 1827$ Merizomyria marina Wangerooge Van Heurck Types du Synopsis des Diatomées de Belgique $\mathrm{n}^{\circ} 234$ Bromfleet near Hull (England) (slide V-27-C12 and unmounted material)

Diatom samples were prepared for light microscopy (LM) observation following the method described in VAN DER WERFF (1955). Small parts of the samples were cleaned by adding $37 \%$ $\mathrm{H}_{2} \mathrm{O}_{2}$ and heating to $80^{\circ} \mathrm{C}$ for about $1 \mathrm{~h}$. The reaction was completed by addition of $\mathrm{KMnO}_{4}$. Following digestion and centrifugation (three times 10 minutes at $3700 \mathrm{~g}$ ), cleaned material was diluted with distilled water to avoid excessive concentrations of diatom valves on the slides. Cleaned diatom material was mounted in Naphrax ${ }^{\circledR}$. The slides were analyzed using an Olympus BX53 microscope, equipped with Differential Interference Contrast (Nomarski) and the Olympus UC30 Imaging System. Samples and slides are stored at the BR-collection (Botanic Garden Meise, Belgium). For scanning electron microscopy (SEM), parts of the oxidized suspensions were filtered through a $2-\mu \mathrm{m}$ Isopore $^{\mathrm{TM}}$ polycarbonate membrane filter (Merck MiLlipore). The stubs were sputter-coated with a Gold-Palladium layer of $20 \mathrm{~nm}$ and studied in a JEOL-JSM-7100F (Botanic Garden Meise, Belgium) and a ZEISS Ultra SEM microscope at $3 \mathrm{kV}$ (Natural History Museum London, UK). Diatom terminology follows Ross et al. (1979) (stria/areola structure), Round et al. (1990) (raphe structure) and Round \& BuKhtiYARova (1996) (genus morphology). The abbreviations RLV and RV are used for the rapheless valve and raphe valve respectively. The morphology of the new taxa has been compared with the ultrastructure of known species described worldwide (Krammer \& LANGE-Bertalot 1991; VAN DE ViJVER et al. 2002; Le CoHU 2005; COMPÈre \& VAN DE ViJver 2009; Álvarez-Blanco \& Blanco 2013).

\section{RESULTS}

In the historic KüTZING material from Wangerooge, two (rare) Planothidium taxa were observed: two valves were identified as $P$. delicatulum (Figs 1-2) whereas the other observed valves belonged to a taxon that has been described by Hustedt in 1939 as Achnanthes linkei (Hustedt 1939), later transferred to Planothidium linkei (Hustedt) Lange-Bertalot 1999 (Figs 3-8). The latter is easily separated from $P$. delicatulum by its much larger valves, the clearly protracted, thin, rostrate apices and the central striae on the rapheless valve that are more distant that all other striae.

\section{Achnanthidium delicatulum Kützing Type material} (Figs 1-2)

Basionym: Achnanthidium delicatulum Kützing 1844, p. 75

Material used: Kützing sample n 1827 Merizomyria marina Wangerooge.

Lectotype (here designated): Slide BR-4461 from gathering Kützing $\mathrm{n}^{\circ} 1827$ in the Van Heurck collection

Table 1. List of samples used in this study

\begin{tabular}{lll}
\hline Sample ID & Geographic locality & Source \\
\hline C-BW501 & Ile de la Possession (Iles Crozet) & unpublished data \\
C-BW510 & Ile de la Possession (Iles Crozet) & unpublished data \\
C-BA27 & Ile de la Possession (Iles Crozet) & VAN DE ViJVER et al. (2002) \\
C-BA99 & Ile de la Possession (Iles Crozet) & VAN DE ViJVER et al. (2002) \\
K-BM372 & Grand Terre (Iles Kerguelen) & VAN DE ViJVER et al. (2001) \\
K-BM510 & Grand Terre (Iles Kerguelen) & unpublished data \\
PEI-D144 & Marion Island (Prince Edward Islands) & VAN DE ViJVER et al. (2008) \\
PEI-D210 & Marion Island (Prince Edward Islands) & VAN DE ViJVER et al. (2008) \\
PEI-D514 & Marion Island (Prince Edward Islands) & VAN DE VIJVER et al. (2008) \\
PEI-G03-188 & Prince Edward Island (Prince Edward Islands) & VAN DE VIJVER et al. (2008) \\
04199120 & Ruffiac (Brittany, France) & ECTOR et al. (2015) \\
\hline
\end{tabular}


(Botanic Garden Meise).

Type locality: "Im Brackwasser der Insel Wangerooge". Light microscopy (Figs 1-2): Valves almost elliptical with convex margins and clearly protracted, cuneaterostrate apices. Valve dimensions $(\mathrm{n}=1)$ : length $18 \mu \mathrm{m}$, width $8.5 \mu \mathrm{m}$ (measurement Kützing: length $16.1 \mu \mathrm{m}$ ). RLV (Fig. 1) Axial area very narrow, clearly linear. Central area absent. Striae parallel to weakly radiate throughout, slightly more radiate towards the apices, 14 in $10 \mu \mathrm{m}$. Areolae not discernible in LM. RV (Fig. 2) Axial area rather narrow, weakly widening towards the central area. Central area rather small, transversely rectangular, never reaching the margins, bordered by 2-3, only slightened shortened striae. Raphe straight, filiform with simple proximal raphe endings. Terminal raphe fissures not discernible in LM. Striae radiate throughout, more radiate towards the apices, ca. 13 in $10 \mu \mathrm{m}$. Areolae not discernible in LM.

Unfortunately, no valves could be observed during SEM analysis.

Achnanthes delicatula (Kützing) Grunow - Types du Synopsis des Diatomées de Belgique n²34 (Figs 9-28) = Planothidium galaicum Álvarez-Blanco et S.Blanco Material used: Van Heurck Types du Synopsis des Diatomées de Belgique $\mathrm{n}^{\circ} 234$ Bromfleet near Hull (England).

Synonyms: Achnanthes delicatula (Kützing) Grunow sensu LangeBerTALOT \& RuPPEL 1980, p. 4, pl. 1, figs 28-31 (“A. delicatula (Kützing) Grunow", Van Heurck, Type de Synopsis no. 234 = Neotypus), non KüTZING 1844, p. 75, pl. 3, fig. 21; Achnanthes delicatula (Kützing) Grunow sensu Lange-Bertalot \& Krammer 1989, p. 44, pl. 80, figs 1-5 (Neotypus, V.H. Type de Synopsis 234); Achnanthes delicatula
(Kützing) Grunow sensu Krammer \& LANGE-Bertalot 1991, p. 71, pl. 39, figs 1-5 (Sippe des Neotypus).

Light microscopy (Figs 9-20) Valves narrowly lanceolate with usually non-protracted, broadly rounded apices. Occasionally apices weakly protracted, subrostrate (Figs $10,12,18)$. Valve dimensions ( $\mathrm{n}=50)$ : length $15-20 \mu \mathrm{m}$, width 5.5-6.5 $\mu \mathrm{m}$. RLV (Figs 9-14) Axial area very narrow, almost linear to weakly lanceolate. Central area absent. Striae equidistant, parallel throughout almost the entire valve, becoming radiate near the apices, 15-17 in $10 \mu \mathrm{m}$. Areolae not discernible in LM. RV (Figs 15-20) Axial area very narrow, linear, only slightly widening towards the central area. Central area very small, rounded to rectangular, bordered by several, irregularly shortened striae. Raphe branches straight, filiform. Proximal raphe endings weakly drop-like expanded, terminal raphe fissures not discernible in LM. Striae strongly radiate throughout the entire valve, weakly geniculate near the central area, 14-16 in $10 \mu \mathrm{m}$. Areolae not discernible in LM.

Scanning electron microscopy (Figs 21-28): RLV (Figs 21-24) Axial area narrow with largest width near the middle of the valve. Striae composed of 5-6 rows of small, rounded areolae, becoming narrower towards the axial area (Figs 22, 23). Small spinules scattered over the entire valve face, mostly (but not exclusively) on the virgae (Figs 22, 23, see arrows). Internally, virgae well developed (Fig. 24). RV (Figs 25-28) Proximal raphe endings enlarged, almost drop-like, straight.
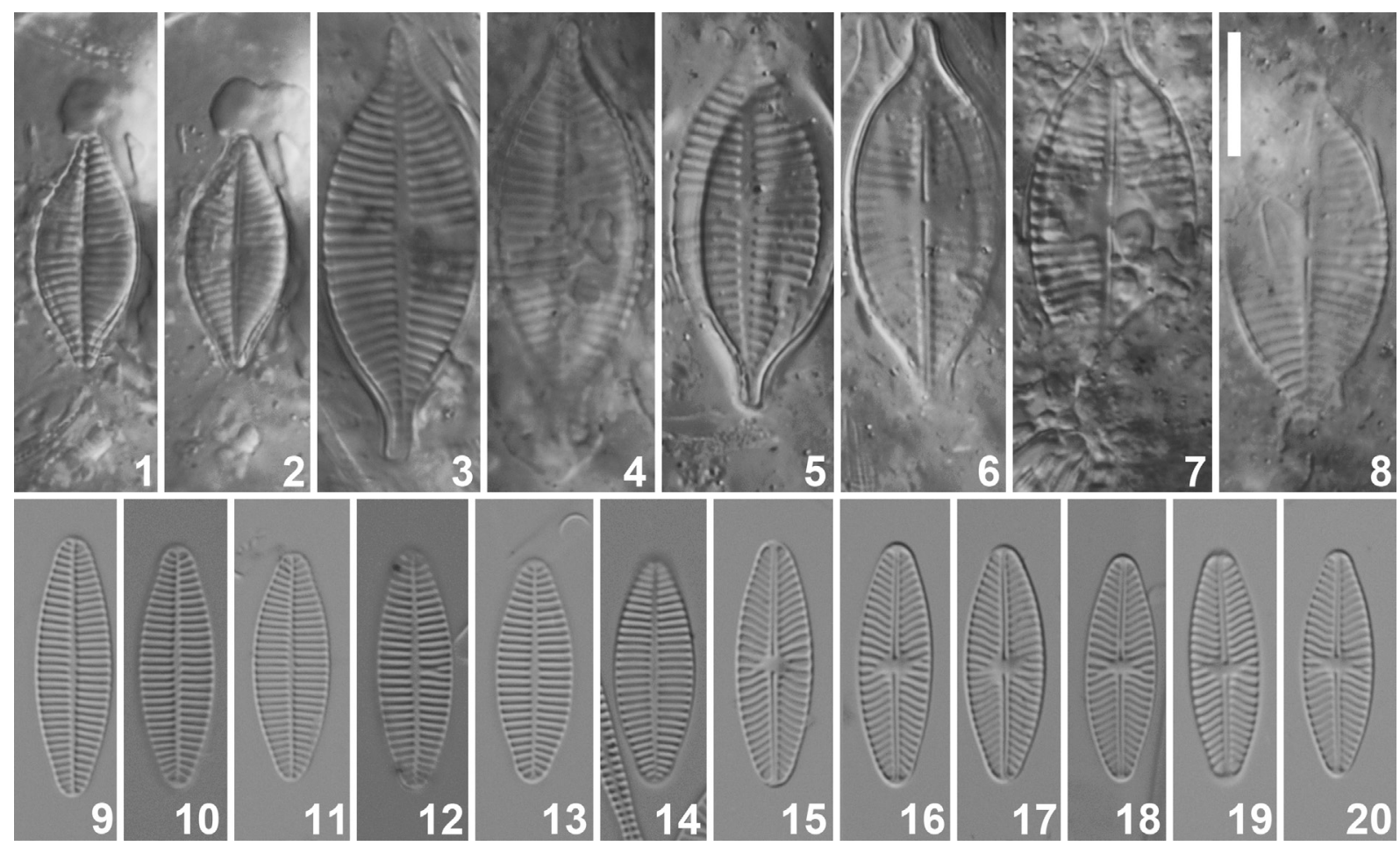

Figs 1-20. Light micrographs of historic diatom material: (1-2) Achnanthidium delicatulum Kützing (Kützing sample $\mathrm{n}^{\circ} 1827$ Merizomyria marina Wangerooge); (3-8) Achnanthes linkei Hustedt (Kützing sample ${ }^{\circ} 1827$ Merizomyria marina Wangerooge); (9-20) Achnanthes delicatula (Kützing) Grunow (= P. galaicum Álvarez-Blanco et S.Blanco) (Van Heurck Types du Synopsis n $\left.{ }^{\circ} 234\right)$. Scale bar $10 \mu \mathrm{m}$. 

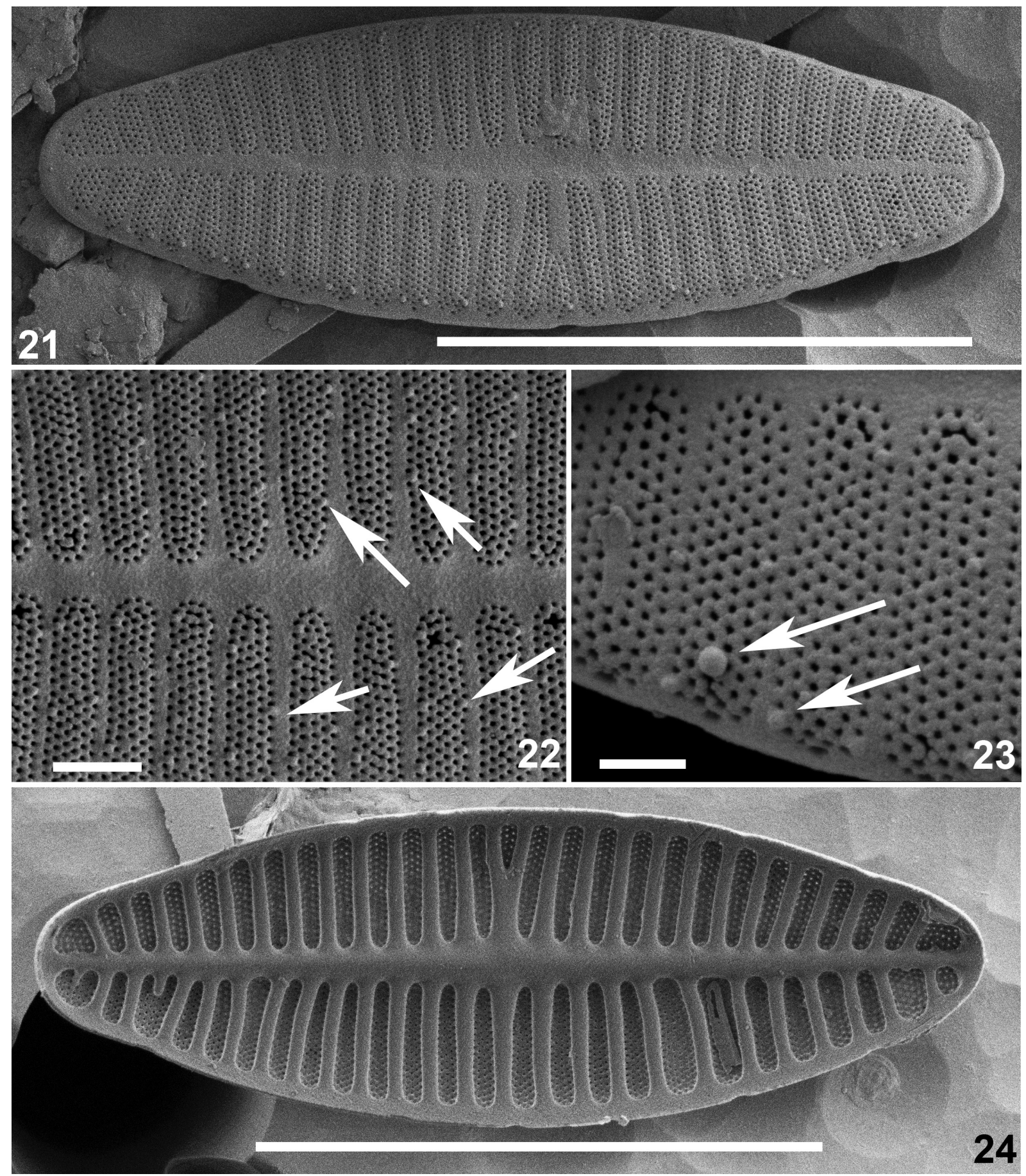

Figs 21-24. Achnanthes delicatula (Kützing) Grunow (= P. galaicum Álvarez-Blanco et S.Blanco) SEM pictures taken from Types du Synopsis $n^{\circ} 234$ : (21) External view of an entire rapheless valve. Note the presence of the small spinules near the valve margin; (22) External detail of the striae near the valve middle. The arrows indicate some of the multiple spinules visible on the valve exterior. (23) External detail of the valve margin with some spinules (see arrows); (24) Internal view of an entire rapheless valve. Scale bars $10 \mu \mathrm{m}(21,24)$ and $1 \mu \mathrm{m}(22,23)$.

Terminal raphe fissures unilaterally bent (Fig. 25). Striae composed of 2-5 rows of small, rounded areolae (Figs 26, 27). Striae near the central area becoming narrower towards the axial area. Near the apices, virgae between the striae becoming extremely narrow to even absent (Fig. 28). External spinules absent (Fig. 25). Internally, proximal raphe endings deflected into opposite directions (Fig. 28). Distal raphe endings terminating on a small helictoglossa (Fig. 28).
Planothidium lilianeanum Van de Vijver sp. nov. (Figs 29-46)

Light microscopy (Figs 29-42): Valves elliptic (smaller valves) to elliptic-lanceolate with clearly cuneately protracted, rostrate apices. Valve dimensions $(n=25)$ : length 11-18 $\mu \mathrm{m}$, width 5.0-6.0 $\mu \mathrm{m}$. RLV (Figs 29-35) Axial area moderately broad, distinctly lanceolate, widening near the central area. Central area absent to asymmetrical weakly widened. Striae equidistant, 16-18 in $10 \mu \mathrm{m}$, 

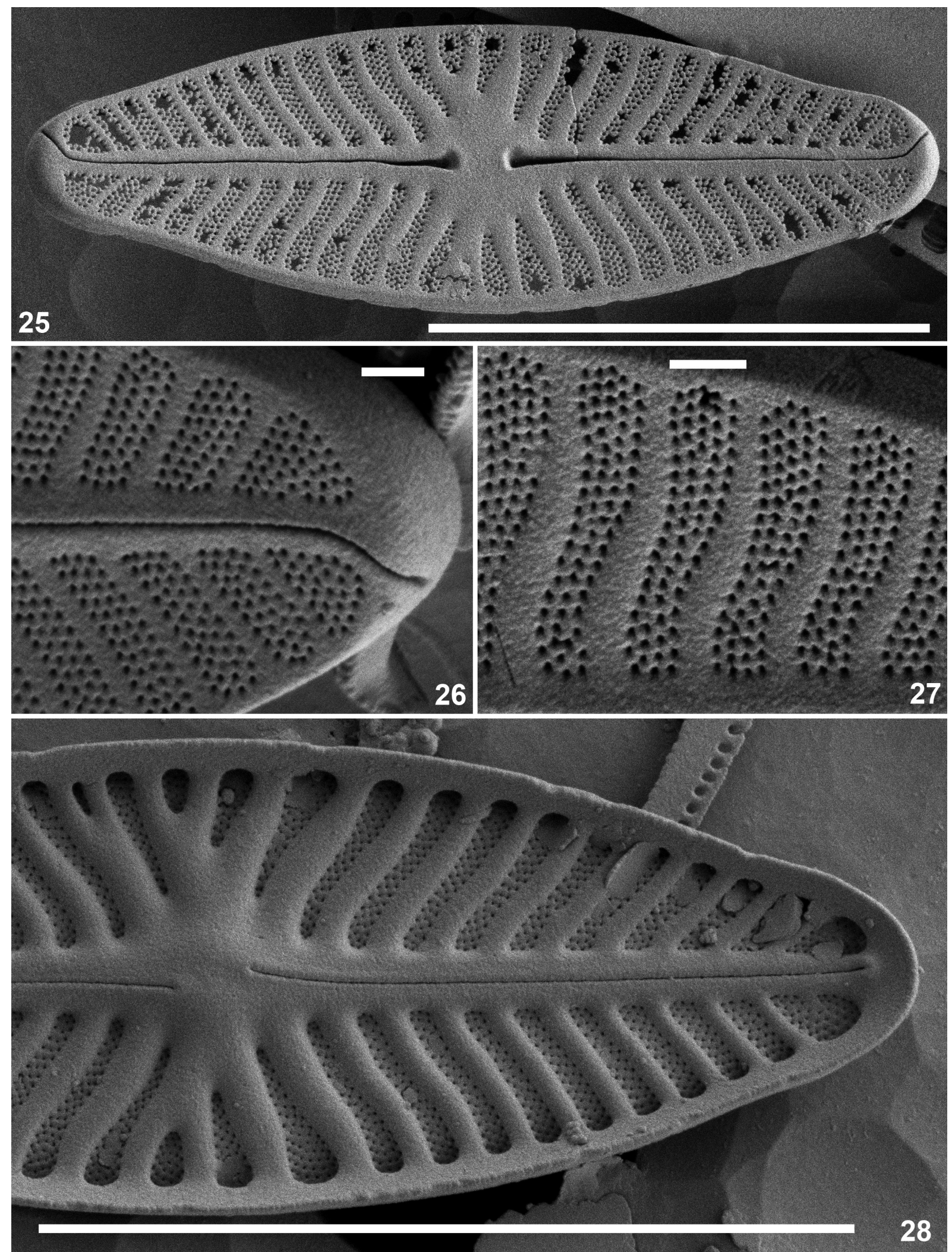

Figs 25-28. Achnanthes delicatula (Kützing) Grunow (= P. galaicum Álvarez-Blanco et S.Blanco) SEM Pictures taken from Types du Synopsis $\mathrm{n}^{\circ}$ 234: (25) External view of an entire raphe bearing valve showing the external raphe branches and the structure of the striae; (26) External detail of the terminal raphe fissure. Fig. 27. External detail of the striae near the valve middle; (34) Internal view of half a raphe bearing valve showing the central area with the proximal raphe endings and the helictoglossa near the valve apex. Scale bars $10 \mu \mathrm{m}(25,28)$ and $1 \mu \mathrm{m}(26,27)$. 

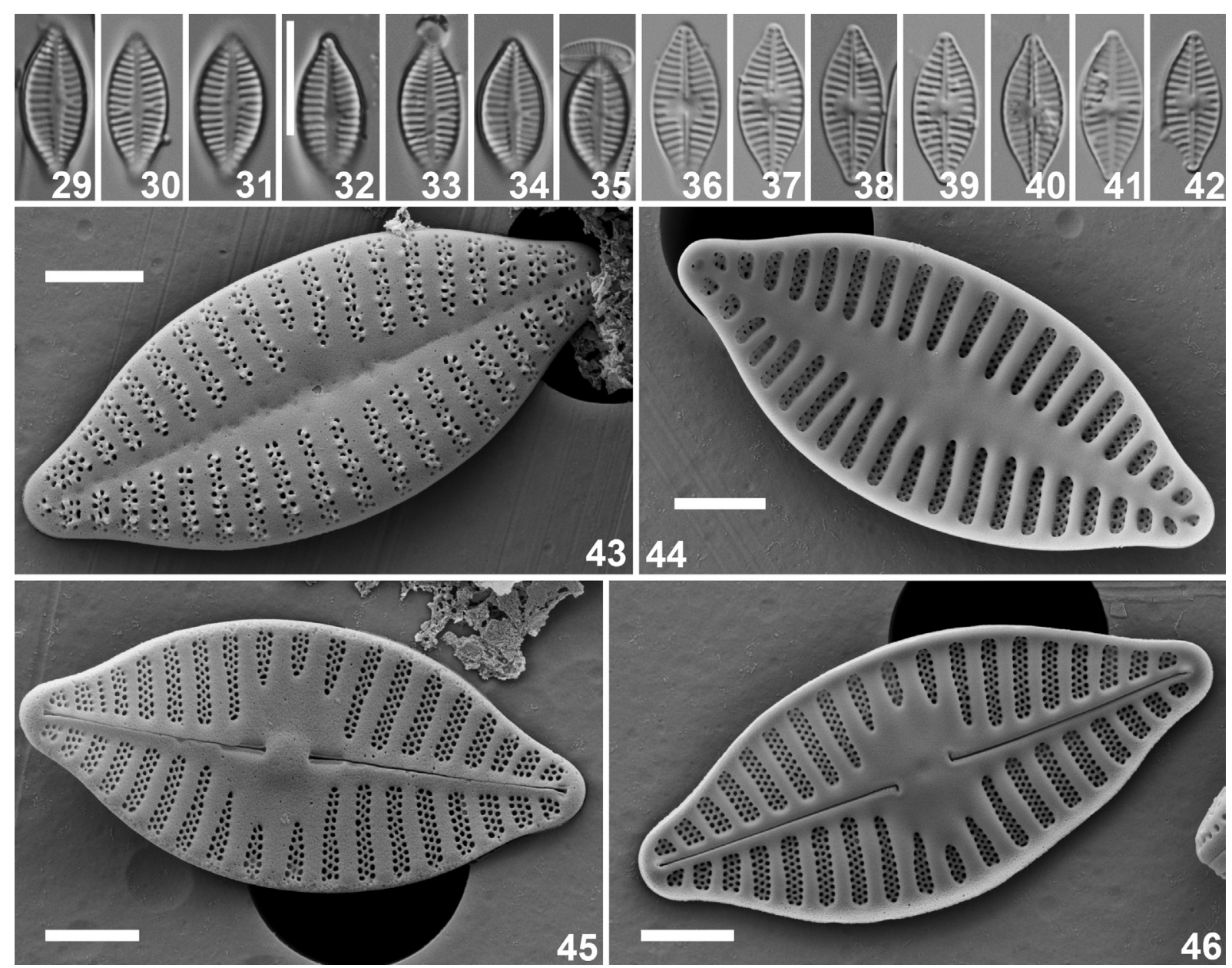

Figs 29-46. Planothidium lilianeanum Van de Vijver sp. nov. All pictures taken from the type locality, Val Studer, Grande Terre, Iles Kerguelen (sample BM372): (29-42) Light micrographs of the type population showing rapheless (29-35) and raphe bearing (36-42) valves; (43) External view of an entire rapheless valve. Note the presence of the small silica outgrowths on the areolae. (44) Internal view of an entire rapheless valve; (45) External view of an entire raphe bearing valve showing the external raphe branches, the short terminal fissures and the structure of the striae; (46) Internal view of an entire raphe bearing valve showing the central area with the proximal raphe endings and the helictoglossa near the valve apex. Scale bars $10 \mu \mathrm{m}(29-42)$ and $2 \mu \mathrm{m}(43-46)$.

showing an asymmetrical pattern with one side having weakly radiate to almost parallel striae and the other side more radiate striae with a shortened striae inserted near the center of the valve. Areolae not discernible in LM. RV (Figs 36-42) Axial area very narrow, linear, only slightly widening towards the central area. Central area rounded to rectangular, bordered by several, irregularly shortened striae. Raphe branches straight, filiform. Proximal raphe endings simple to weakly expanded, terminal raphe fissures not discernible in LM. Striae strongly radiate throughout the entire valve, more radiate near the apices, $16-18$ in $10 \mu \mathrm{m}$. Areolae not discernible in LM.

Scanning electron microscopy (Figs 43-46): RLV (Figs 43-44) Axial area rather broad with the largest width near the middle of the valve. Striae composed of 2 rows of large, rounded areolae, with a third row of very small areolae inserted between the large areolae (Fig. 43). Small silica outgrowths covering some of the areolae, only present on the striae, never on the virgae or the axial area. Internally, virgae well developed (Fig. 44). RV (Figs 45-46) Proximal raphe endings straight, located in narrow, elongated grooves. Terminal raphe fissures short, straight, weakly enlarged (Fig. 45). Striae composed of 3 rows of rather large, rounded areolae, the middle row occasionally slightly smaller than the outer rows (Fig. 45). Striae near the central area becoming narrower towards the axial area. Near the apices, virgae becoming extremely narrow to even absent (Fig. 46). Internally, proximal raphe endings hooked into opposite directions (Fig. 46). Distal raphe endings terminating on a small helictoglossa (Fig. 46).

Holotype: BR-4520 (Botanic Garden Meise, Belgium) Isotypes: PLP-346 (University of Antwerp, Belgium) Type locality: Val Studer, Grand-Terre, Iles Kerguelen, sample BM372 (Leg. B. Van de Vijver; coll. date 04/02/1998) (49¹7'08.7"S, 70²'59.5"E).

Etymology: the species is named after my dear friend and colleague, Mrs. Liliane Tytens (Botanic Garden Meise), in recognition of her work as botanical illustrator.

Ecology and distribution: Planothidium lilianeanum 


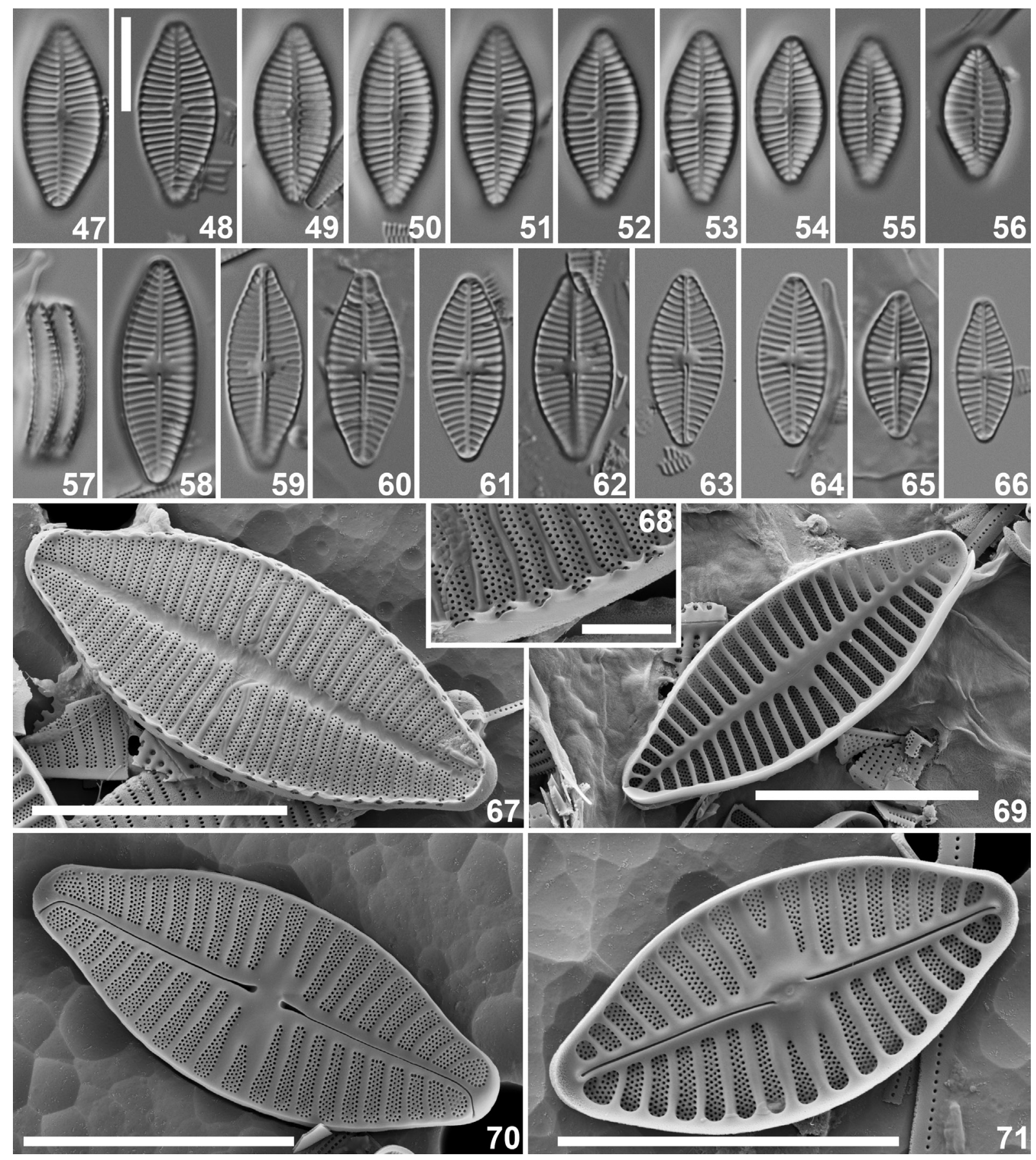

Figs 47-71. Planothidium australodelicatulum Van de Vijver, C.E. Wetzel et Ector sp. nov. All pictures taken from the type locality, Ship's Cove, Marion Island, Prince Edward Islands (sample PEI-D514): (47-66) Light micrographs of the type population showing rapheless (47-56) and raphe bearing (57-66) valves; (67) External view of an entire rapheless valve. Note the presence of the crescent moon shaped silica ridges on the virgae near the margins; (68) External detail of the valve margin with the crescent moon shaped silica ridges; (69) Internal view of an entire rapheless valve; (70) External view of an entire raphe bearing valve showing the external raphe branches, with weakly deflected proximal raphe endings and the structure of the striae; (71) Internal view of an entire raphe bearing valve showing the central area with the proximal raphe endings and the helictoglossa near the valve apex. Scale bars $10 \mu \mathrm{m}(47-67,69-71)$, and $1 \mu \mathrm{m}(68)$.

was found in several samples collected near the Lac Studer, a large lake in the inland of Grande Terre, the main island of the Kerguelen Archipelago. The largest populations were found living on wet mosses on the shore of the lake. PH of the water dripping through and over the mosses varied around 7.3 with a conductivity of $230 \mu \mathrm{S} . \mathrm{cm}^{-1}$. So far, the species has not been found on the other islands in the southern Indian Ocean, despite an intensive sampling campaign on all islands.

\section{Planothidium australodelicatulum Van de Vijver,} C.E.Wetzel et Ector sp. nov. (Figs 47-71)

Light microscopy (Figs 47-66): Frustules in girdle view clearly bent about the transapical axis (Fig. 57). Valves 



Figs 72-102. Planothidium delicatulum (Kützing) Round et Bukhtiyarova. All pictures taken from Arches Creek at Ruffiac in Brittany, France: (72-98) Light micrographs of the population showing rapheless (72-85) and raphe bearing (86-98) valves; (99) External view of an entire rapheless valve; (100) External view of an entire raphe bearing valve showing the external raphe branches, the short terminal fissures and the structure of the striae; (101) Internal view of an entire rapheless valve; (102) Internal view of an entire raphe bearing valve showing the central area with the proximal raphe endings and the helictoglossa near the valve apex. Scale bars $10 \mu \mathrm{m}$.

elliptic-lanceolate with short, cuneately protracted, rostrate apices. Valve dimensions $(\mathrm{n}=25)$ : length 14-24 $\mu \mathrm{m}$, width 6.0-8.0 $\mu \mathrm{m}$. RLV (Figs 47-56) Axial area very narrow, linear, slightly asymmetrically widening near the central area. Central area absent to asymmetrical weakly widened with 1-2 very slightly shortened striae on one side. Striae equidistant, radiate, becoming strongly radiate towards the apices, $13-14$ in $10 \mu \mathrm{m}$. Areolae not discernible in LM. RV (Figs 58-66) Axial area very narrow, linear, widening towards the central area. Central area small, rounded, bordered by several, irregularly shortened striae. Raphe branches straight, filiform. Proximal raphe endings clearly expanded, straight to weakly deflected. Terminal raphe fissures not discernible in LM. Striae weakly radiate near the valve center, becoming strongly radiate near the apices, 12-14 in $10 \mu \mathrm{m}$. Areolae not discernible in LM.

Scanning electron microscopy (Figs 67-71): RLV (Figs 67-69) Axial area very narrow, clearly linear, forming an irregularly shaped shallow, forming an irregularly shaped shallow groove. Striae slightly raised, separated by thickened shallow virgae. Striae composed of 4-5 rows of small, rounded areolae, never becoming narrower near the axial area (Fig. 67). Near the valve margins, small, crescent moon shaped low ridges present terminating each virga (Figs 67, 68). Striae continuing with a few areolae on the valve mantle (Fig. 68). Internally, virgae well developed (Fig. 69). RV (Figs 70-71) Proximal raphe endings enlarged, almost drop-like, weakly deflected. Terminal raphe fissures unilaterally bent (Fig. 70). Striae 
composed of 4-5 rows of small, rounded areolae (Fig. 70). Striae near the central area becoming narrower towards the axial area. Central striae (1-2) shortened. Near the apices, virgae between the striae becoming narrower (Fig. 70). Internally, proximal raphe endings short, deflected into opposite directions (Fig. 71). Distal raphe endings terminating on a small helictoglossa (Fig. 71).

Holotype: BR-4520 (Botanic Garden Meise, Belgium) Isotypes: PLP-347 (University of Antwerp, Belgium) Type locality: Ship's Cove, Marion Island, Prince Edward Islands, sample D514 (Leg. N. Gremmen; coll. date $22 / 04 / 2003)\left(46^{\circ} 51^{\prime} 17.7^{\prime \prime S}, 37^{\circ} 50^{\prime} 39.7^{\prime \prime E}\right)$.

Etymology: the specific epithet refers to the close similarity with $P$. delicatulum and the biogeographical distribution of this species in the southern hemisphere.

Ecology and distribution: Planothidium australodelicatulum has been found on several sub-Antarctic islands in the southern Indian Ocean. The species was observed on the Prince Edward Islands, Iles Crozet (VAN DE VIJVER et al. 2002) and Iles Kerguelen (Le CoHU 2005). The largest population was found in a small seal wallow ( $\mathrm{pH}$ 6.2) on Marion Island (Prince Edward islands) located on some coastal rocks. The influence of marine mammals (i.c. elephant seals) was clearly visible. On Ile de la Possession (Iles Crozet), the species was found in a several small, several small shallow lakes close to the ocean, on various localities on the island. The $\mathrm{pH}$ of the lakes ranged from 7.4 to 9.4 with a conductivity ranging from 300 to more than $3000 \mu \mathrm{S} . \mathrm{cm}^{-1}$. The influence of marine birds and mammals and sea spray was quite visible (Van de Vijver, pers. obs.).

\section{DiscuSSION}

Planothidium delicatulum is a widespread species in both marine and brackish environments (e.g., SNOEIJs 1993; Riaux-Gobin et al. 2018). LANGE-BERTALOT \& KRAMMER (1989) grouped several of these forms as one Achnanthes delicatula-complex. The absence of an analysis of the type material resulted in a long lasting confusion about the correct identity of this species. Based on literature data, the species seems to have a worldwide distribution (e.g., Servant-VILDARY \& Roux 1990; WitKowsKi 1991; CAMPEAU et al. 1999; LANGE \& TIFFANy 2002; BLANCO LANZA et al. 2010), often reported as varieties of forms or erroneously under different names such as Achnanthes hauckiana Grunow (TROPPER 1975). Several of these records show however valves with a vague resemblance to $P$. delicatulum s.s. but it is clear that they need to be reanalyzed to determine their correct taxonomic identity (see for instance WITON \& WITKOWSKI 2006 or BUCZKó et al. 2009).

The valves described and illustrated by KüTZING as Achnanthidium delicatulum (see ÁlvarEZ-BLANCO \&
BLANCO 2013, figs 26-32) show typically broadly rounded, almost elliptical valves with clearly protracted, almost capitate apices. Figures 72-101 show light and scanning electron microscopy illustrations of a Planothidium delicatulum population from Arches Creek at Ruffiac in Brittany, France (sampling date: 21/07/2009). The valves are conspecific with the type of $P$. delicatulum allowing a better understanding of the ultrastructure of the valves.

Analysis of the Wangerooge type material did not yield a lot of valves but based on the few LM observations of Achnanthidium delicatulum, it is clear that the neotype designated by Lange-Bertalot (in LANGE-BERTALOT \& RUPPEL 1980) based on the Van Heurck material (Types du Synopsis $n^{\circ} 234$ ) is not conspecific with Achnanthidium delicatulum and should, for reasons mentioned above in the introduction and in Álvarez-BlanCo \& BlANCO (2013), be separated from $P$. delicatulum. The scanning electron microscopy observations showed that this population is conspecific with $P$. galaicum a species described in 2013 by Álvarez-Blanco \& Blanco. This conspecificity was however not discussed by ÁlvarEZ-BLANCO \& BLANCO (2013). SEM analysis of the Van Heurck material shows the presence of identical small spinules on the RLV. The population in Van Heurck Types $n^{\circ} 234$ shows larger valves (length 15-20 vs. 9-15 in the type material of $P$. galaicum) and given similar valve widths for both population, this difference in valve length gives the population in Van Heurck $n^{\circ} 234$ a more slender, elongated valve outlook. Nevertheless, we believe that both taxa are conspecific based on their identical striation patterns and the presence of the spinules.

Several Planothidium delicatulum populations were reported from the Antarctic Region (SCHMIDT et al. 1990; WASELL \& HÅKANSSON 1992; VAN DE VIJVER et al. 2002; Le COHU 2005). The genus Planothidium is represented in the Antarctic region by more than 10 species. Most of these species belong to the lanceolatum-type. Within Planothidium, several types can be distinguished based on the structure of the rapheless valve: species with a hoof-mark (occasionally capped) depression on the RL valve (lanceolatum-type), small (maximum valve length $<12 \mu \mathrm{m}$ ) species with a continuous striation pattern on the RL valve (granum-type) and large species (minimum valve length $>12 \mu \mathrm{m}$ ) with a continuous striation pattern on the RL valve (delicatulum-type). Most species in the Antarctic Region belong to the lanceolatum-type [e.g., P. cyclophorum (Heiden) Van de Vijver, $P$. rostrolanceolatum Van de Vijver et al., $P$. frequentissimum (Lange-Bertalot) Lange-Bertalot, $P$. aueri (Krasske) Lange-Bertalot) or the granum-type (e.g., P. quadripunctatum (Oppenheim) Sabbe, P. renei (Lange-Bertalot et Rol.Schmidt) Van de Vijver, $P$. wetzelectorianum Kopalová et al.] (VAN DE VIJVER et al. 2002, 2013; Kopaloví et al. 2016).

Only two taxa from the delicatulum-type were reported: $P$. delicatulum and $P$. australe (VAN DE ViJver et al. 2002; Le CoHu 2005; Zidarova et al. 2016). Planothidium delicatulum has been frequently 
reported (usually as Achnanthes delicatula or A. linkei Hustedt) from the Maritime Antarctic Region (mainly the archipelagos of the South Shetland Islands and the South Orkney Islands) and the sub-Antarctic Islands. KellogG \& KellogG (2002) listed more than 30 records of $A$. delicatula up to 2002. Analysis of the illustrated (using LM or SEM) records showed that all records from the Maritime Antarctic Region (e.g., SCHMIDT et al. 1990; WASELL \& HÅKANSSON 1992; OPPENHEIM 1994) belonged to Planothidium australe (Manguin in Bourrelly et Manguin) Le Cohu (ZIDARova et al. 2016). As not all published records were illustrated, it is unclear whether P. delicatulum s.s. is present in the Maritime Antarctic Region (Van de Vijver, pers. obs.). The situation seemed to be different in the sub-Antarctic Region. VAN DE VIJVER et al. (2002) illustrated several populations from Ile de la Possession (Iles Crozet) showing some affinity with P. delicatulum s.l. However, Planothidium lilianeanum presents several differences that separate the species from $P$. delicatulum. Valves of $P$. lilianeanum have a more elliptical valve outline with short, typically cuneately protracted, rostrate apices, which is rather similar to the two valves that were found in the type material of $P$. delicatulum. The axial area of the rapheless valve in $P$. lilianeanum is clearly lanceolate and quite broad compared to the narrow, linear axial area in P. delicatulum. The central area in the raphe bearing valve in $P$. delicatulum is very small, which is in contrast with the relatively large, rounded to rectangular central area in $P$. lilianeanum. The observed valves in the $P$. delicatulum type slide have a valve width of $8.5 \mu \mathrm{m}$, significantly larger than the valve width in P. lilianeanum (5.0-6.0 $\mu \mathrm{m})$. Although the ultrastructure of $P$. delicatulum could not be examined, the observed differences in LM are sufficient to exclude conspecificity. Ecologically, both species are quite different. Planothidium lilianeanum was found in several moss samples collected from a circumneutral, fast-flowing river on Iles Kerguelen, more than $20 \mathrm{~km}$ inland and thus out of the influence of the ocean. On the other hand, $P$. delicatulum was described from a brackish sample on the Wangerooge Island in Germany. Planothidium hauckianum (Grunow) Round et Bukhtiyarova is sufficiently different based on its elongated, lanceolate valve outline, its low stria density (9-10 striae in $10 \mu \mathrm{m}$ ) and its typical brackish ecology to avoid confusion with $P$. lilianeanum (KRAMMER \& LANGE-Bertalot 1991). Hustedt described in 1937 Achnanthes lacunarum var. fonticola from a waterfall on Java (SCHMIDT et al. 1937). The species has a rather similar valve outline, but the rapheless valve has a very large axial area with only short marginal striae (SCHMIDT et al. 1937, plate 409, figs 64-67). Planothidium australe, originally described by Manguin (in BOURRELLY \& MANGuIN 1954) as A. delicatula var. australis Manguin, has an elliptical to elliptical-lanceolate valve outline with clearly and long protracted, rostrate apices. Analysis of slide 178 of the Manguin collection (slide Manguin AD 9085 from the Musée d'Histoire naturelle de Paris), from which $P$. australe was originally described, showed unfortunately no valves identical to the original description and drawing (see Bourrelly \& MANGUin 1954, p. 20, plate 2, figs 18a\&b). Le COHU (2005) and Zidarova et al. (2016) illustrated several Antarctic populations from Iles Kerguelen and the Maritime Antarctic Region, showing clearly that $P$. australe is sufficiently different from both new species to exclude all conspecificity.

Planothidium australodelicatulum resembles $P$. delicatulum. Since no valves were found during SEM analysis of the type material and only two valves were present in the investigated LM type slide, it is not obvious to separate both species. Planothidium has a more elliptical valve outline with shortly protracted, rather narrow cuneate-rostrate apices whereas $P$. australodelicatulum has a more elliptic-lanceolate valve outline with bluntly rounded, shortly protracted apices. The central area in $P$. australodelicatulum seems larger than in P. delicatulum. Although the ultrastructure of the type material of $P$. delicatulum could not be compared, the SEM pictures made from the French population that could be identified as $P$. delicatulum show marked differences in their ultrastructure. The two main differences are related to the structure of the striae and the valve surface and the presence/absence of the crescent moon shaped ridges. The rapheless valve of $P$. delicatulum illustrated in SNOEIJS (1993) shows the very narrow to almost completely absent virgae between the striae whereas $P$. australodelicatulum has clearly developed, thickened virgae. Moreover, the crescent moon shaped ridges at the end of the virgae in $P$. australodelicatulum are entirely absent in P. delicatulum. In fact, none of the illustrated valves of $P$. delicatulum in the northern hemisphere (e.g., Yамамото et al. 2017) show similar crescent moon shaped ridges whereas all observed populations of $P$. australodelicatulum in the southern Indian Ocean possess these ridges. Planothidium australodelicatulum also shows some resemblance to two other Planothidium taxa: P. iberense Rovira et Witkowski and P. densistriatum Van de Vijver et Beyens. Planothidium iberense, described from the Ebro Estuary (Rovira et al. 2011), shows a similar valve outline but the rapheless valve has a typical, conspicuous, asymmetrical central area, never observed in any population of $P$. australodelicatulum. Moreover, $P$. iberense lacks the crescent moon shaped ridges. The striae in $P$. iberense have usually a lower number of areolae per stria (2-4) whereas in $P$. australodelicatulum, several striae show 4-5 rows of areolae. Finally, Planothidium densistriatum, described from Ile de la Possession (Iles Crozet) is found in similar habitats as $P$. australodelicatulum and often co-occurs (VAN DE VIJVER et al. 2002). Both taxa share the presence of the crescent moon shaped ridges but they can however easily be separated as $P$. densistriatum has a much more elliptical (broader, 7-12 $\mu \mathrm{m}$ ) valve outline, a higher number of striae (17-23 in $10 \mu \mathrm{m}$ in the rapheless valve) and extremely narrow, almost absent virgae. Conspecificity is therefore excluded. 


\section{ACKNOWLEDGEMENTS}

Dr. N.J.M. Gremmen is thanked for providing the samples of Marion Island. Sampling on Iles Crozet and Iles Kerguelen was made possible with the logistic and financial support of the Institut Polaire Français - Paul-Emile Victor (IPEV) in the frame of the Terrestrial Ecology program 136 (Yves Frenot \& Marc Lebouvier). This study was further supported by the BELSPO MICROBIAN project to visit the National History Museum in London, UK. Alex Ball, Tomasz Goral and the staff of the IAC laboratory at the Natural History Museum are thanked for their help with the scanning electron microscopy.

\section{REFERENCES}

Álvarez-Blanco, I. \& Blanco, S. (2013): Planothidium galaicum sp. nov. (Bacillariophyta, Achnanthidiaceae), a new diatom species from Galician coast, Spain. - Phytotaxa 151: 44-52. https://doi.org/10.11646/ phytotaxa.151.1.4

Blanco Lanza, S.; Cejudo Figueiras, C.; Álvarez Blanco, I.; BÉCARes Mantecón, E.; HoffManN, L. \& ECtOr, L. (2010): Atlas de las Diatomeas de la cuenca del Duero / Diatom Atlas of the Duero Basin. - 382 pp., Área de Publicaciones, Universidad de León, León.

Bourrelly, P. \& MANGuin, E. (1954): Contribution à la flore algale d'eau douce des Iles Kerguelen. - Mémoires de 1'Institut Scientifique de Madagascar, Série B, 5: 7-58.

Buczkó, K.; Magyari, E.; Stenger-Kovács, C. \& Korponai, J. (2009): The Holocene diatom flora of Zalavári pond (Lake Balaton system, Hungary). - Algological Studies 132: 35-73. https://doi.org/10.1127/1864-1318/2009/0132-0035

Campeau, S.; Pienitz, R. \& Héquette, A. (1999): Diatoms from the Beaufort Sea coast, southern Arctic Ocean (Canada). Modern analogues for reconstructing Late Quaternary environments and relative sea levels. Bibliotheca Diatomologica 42: 1-244.

Compère, P. \& VAN DE ViJver, B. (2009): Planothidium engelbrechtii (Cholnoky) Round \& Bukhtiyarova: Identity and lectotypification (Bacillariophyta). - Fottea 9: 187-192. https://doi.org/10.5507/fot.2009.019

Ector, L.; Wetzel, C.E.; Novais, M.H. \& Guillard, D. (2015). Atlas des diatomées des rivières des Pays de la Loire et de la Bretagne. - 649 pp., DREAL Pays de la Loire, Nantes.

Frenot, Y.; Gloaguen, J.-C.; Van de Vijver, B. \& Beyens, L. (1997): Datation de quelques sédiments tourbeux holocènes et oscillations glaciaires aux îles Kerguelen [Datation of some holocene peat sediments and glacier fluctuations in the Kerguelen islands]. - Comptes Rendus de l'Académie des Sciences, Série III, Sciences de la Vie - Life Sciences 320: 567-573. https://doi. org/10.1016/S0764-4469(97)84712-9

HustedT, F. (1939): Die Diatomeenflora des Küstengebietes der Nordsee vom Dollart bis zur Elbemündung. I. Die Diatomeenflora in den Sedimenten der unteren Ems sowie auf den Watten in der Leybucht, des Memmert und bei der Insel Juist. - Abhandlungen des Naturwissenschaftlichen Verein zu Bremen 31: 571-677.

KellogG, T.B. \& KellogG, D.E. (2002): Non-marine diatoms and littoral diatoms from Antarctic and subantarctic regions. Distribution and updated taxonomy. - Diatom Monographs 1: 1-795.

Kopalová, K.; Zidarova, R. \& VAN DE ViJver, B. (2016): Four new monoraphid diatom species (Bacillariophyta, Achnanthaceae) from the Maritime Antarctic Region.
- European Journal of Taxonomy 217: 1-19. https:// doi.org/10.5852/ejt.2016.217

Krammer, K. \& LANGe-Bertalot, H. (1991): Süsswasserflora von Mitteleuropa 2: Bacillariophyceae 4. Teil: Achnanthaceae. Kritische Ergänzungen zu Navicula (Lineolatae) und Gomphonema. Gesamtliteraturverzeichnis Teil 1-4. - 433 pp., Gustav Fischer Verlag, Stuttgart - Jena.

KÜTZING, F.T. (1844): Die kieselschaligen Bacillarien oder Diatomeen. - 152 pp., 30 pl., W. Köhne, Nordhausen. https://doi.org/10.5962/bhl.title.64360

Lange, C.B. \& TiffanY, M.A. (2002): The diatom flora of the Salton Sea, California. - Hydrobiologia 473: 179-201. https://doi.org/10.1023/A:1016550205461

LANGe-Bertalot, H. (1999): Neue Kombinationen von Taxa aus Achnanthes Bory (sensu lato). - Iconographia Diatomologica 6: 276-289.

Lange-Bertalot, H. \& Krammer, K. (1989): Achnanthes eine Monographie der Gattung mit Definition der Gattung Cocconeis und Nachträgen zu den Naviculaceae. Bibliotheca Diatomologica 18: 1-393.

Lange-Bertalot, H. \& Ruppel, M. (1980): Zur Revision taxonomisch problematischer, ökologisch jedoch wichtiger Sippen der Gattung Achnanthes Bory [A revision of some taxonomically most problematic groups in Achnanthes Bory, important from the ecological point of view]. - Algological Studies 26: 1-31.

LE CoHU, R. (2005): Révision des principales espèces dulçaquicoles d'Achnanthales (Bacillariophyta) des îles subantarctiques de Kerguelen [Revision of the main freshwater species of Achnanthales (Bacillariophyta) from sub-antarctic Iles Kerguelen]. - Algological Studies 116: 79-114. https://doi.org/10.1127/1864-1318/2005/0116-0079

Le Cohu, R. \& Maillard, R. (1983): Les diatomées monoraphidées des îles Kerguelen [The diatoms «monoraphidinae» in the Kerguelen islands]. - Annales de Limnologie - International Journal of Limnology 19: 143-167. https://doi.org/10.1051/limn/1983018

McNeill, J.; Barrie, F.R.; Buck, W.R.; Demoulin, V.; Greuter, W.; Hawksworth, D.L.; Heredeen, P.S.; Knapp, S.; Marhold, K.; Prado, J.; Prud'Homme van Reine, W.F.; SMith, G.F.; Wiersema, J.H. \& TuRLAND, N.J. (2012): International Code of Nomenclature for algae, fungi, and plants (Melbourne Code). - Regnum Vegetabile 154: 1-208.

Oppenheim, D.R. (1994): Taxonomic studies of Achnanthes (Bacillariophyta) in freshwater maritime antarctic lakes. - Canadian Journal of Botany 72: 1735-1748. https://doi.org/10.1139/b94-214

RiauX-Gobin, C.; WitKowski, A.; Igersheim, A.; LobBan, C.S.; Al-HANDAl, A.Y. \& CoMpère, P. (2018): Planothidium juandenovense sp. nov. (Bacillariophyta) from Juan de Nova (Scattered Islands, Mozambique Channel) and other tropical environments: A new addition to the Planothidium delicatulum complex. - Fottea 18: 106-119. https://doi.org/10.5507/fot.2017.01

Ross, R.; Cox, E.J.; Karayeva, N.I.; ManN, D.G.; Paddock, T.B.B; SimOnSEN, R. \& Sims, P.A. (1979): An amended terminology for the siliceous components of the diatom cell. - Nova Hedwigia, Beiheft 64: 513-533.

Round, F.E. \& BukHtiYARova, L. (1996): Four new genera based on Achnanthes (Achnanthidium) together with a re-definition of Achnanthidium. - Diatom Research 11: 345-361. https://doi.org/10.1080/0269 249X.1996.9705389

Round, F.E.; Crawford, R.M. \& Mann, D.G. (1990): The 
diatoms. Biology \& morphology of the genera. - 747 pp., Cambridge University Press, Cambridge.

Rovira, L.; Witkowski, A.; Trobajo, R.; Ruppel, M. \& IBÁÑEZ, C. (2011): Planothidium iberense sp. nov., a new brackish diatom of the Ebro Estuary, northeast Spain. - Diatom Research 26: 99-107. https://doi.or g/10.1080/0269249X.2011.587645

Schmidt, A. et al. (1937): Atlas der Diatomaceen-kunde, Series VIII (Heft 103). - pls. 409-412 [F. HustedT], O.R. Reisland, Leipzig.

SCHMidt, R.; MäUSBACHER, R. \& MÜLleR, J. (1990): Holocene diatom flora and stratigraphy from sediment cores of two Antarctic lakes (King George Island). - Journal of Paleolimnology 3: 55-74. https://doi.org/10.1007/ BF00209300

Servant-Vilddary, S. \& Roux, M. (1990): Multivariate analysis of diatoms and water chemistry in Bolivian saline lakes. - Hydrobiologia 197: 267-290. https://doi. org/10.1007/978-94-009-0603-7_23

Snoeiss, P. (ed.) (1993): Intercalibration and distribution of diatom species in the Baltic Sea. Volume 1. - The Baltic Marine Biologists Publication 16a: 1-129, Opulus Press AB, Uppsala.

Tropper, C.B. (1975): Morphological variation of Achnanthes hauckiana (Bacillariophyceae) in the field. - Journal of Phycology 11: 297-302. https://doi. org/10.1111/j.1529-8817.1975.tb02782.x

VAN DER WERFF, A. (1955): A new method of concentrating and cleaning diatoms and other organisms. - Internationale Vereinigung für Theoretische und Angewandte Limnologie Verhandlungen 12: 276-277. https://doi.org/10.1080/ 03680770.1950.11895297

VAn de ViJver, B.; Ledeganck, P. \& Beyens, L. (2001): Habitat preferences in freshwater diatom communities from sub-Antarctic Îles Kerguelen. - Antarctic Science 13: 28-36. https://doi.org/10.1017/S0954102001000050

VAn de VijVer, B.; Frenot, Y. \& Beyens, L. (2002): Freshwater diatoms from Ile de la Possession (Crozet Archipelago, Subantarctica). - Bibliotheca Diatomologica 46: 1-412.

VAn de Vijver, B.; Gremmen, N. \& SMith, V. (2008): Diatom communities from the sub-Antarctic Prince Edward Islands: diversity and distribution patterns. - Polar
Biology 31: 795-808. https://doi.org/10.1007/ s00300-008-0418-Z

Van de Vijver, B.; Wetzel, C.; Kopalová, K.; Zidarova, R. \& ECTOR, L. (2013): Analysis of the type material of Achnanthidium lanceolatum Brébisson ex Kützing (Bacillariophyta) with the description of two new Planothidium species from the Antarctic Region. Fottea 13: 105-117. https://doi.org/10.5507/fot.2013.010 VAn HeurcK, H. (1880-1885): Synopsis des Diatomées de Belgique. - Atlas, pl. 1-30 (1880), Texte, 235 pp. (1885), Imprimerie Martin Brouwers \& Co., Anvers.

Yамамото, M.; ChiвA, T. \& Tuji, A. (2017): Salinity responses of benthic diatoms inhabiting tidal flats. - Diatom Research 32: 243-250. https://doi.org/10.1080/0269 249X.2017.1366951

Wasell, A. \& HÅKansson, H. (1992): Diatom stratigraphy in a lake on Horseshoe Island, Antarctica: a marinebrackish-fresh water transition with comments on the systematics and ecology of the most common diatoms. - Diatom Research 7: 157-194. https://doi.org/10.10 80/0269249X.1992.9705205

Witкowski, A. (1991): Diatoms of the Puck bay coastal shallows (Poland, Southern Baltic). - Nordic Journal of Botany 11: 689-701. https://doi.org/10.1111/j.1756-1051.1991. tb01280.x

Witon, E. \& Witkowski, A. (2006): Holocene diatoms (Bacillariophyceae) from Faeroe Islands fjords, Northern Atlantic Ocean. II. Distribution and taxonomy of marine taxa with special reference to benthic forms. - Diatom Research 21: 175-215. https://doi.org/10.1080/02692 49X.2006.9705658

Zidarova, R.; Kopalová, K. \& VAN de ViJver, B. (2016): Ten new Bacillariophyta species from James Ross Island and the South Shetland Islands (Maritime Antarctic Region). - Phytotaxa 272: 37-62. https://dx.doi. org/10.11646/phytotaxa.272.1.2

(C) Czech Phycological Society (2018)

Received January 26, 2017

Accepted March 15, 2017 